\title{
A Review of the Implementation of Badminton Extracurricular Activities at SMAN 12 Padang
}

\author{
Doni Jalpa*, Maidarman, Zarwan, Ishak Aziz \\ Faculty of Sport Sciences, Universitas Negeri Padang, Prof. Dr. Hamka, Padang, Indonesia \\ ${ }^{*}$ Corresponding author.Email: donijalpa33@gmail.com
}

\begin{abstract}
This research belongs to the type of descriptive research which aims to find out about the implementation of badminton extracurricular activities at SMAN 12 Padang. Sampling is done by using total sampling technique, namely the population sampled, because the population is less than 100 people. The data collection technique is conducted by observing and distributing questionnaires to students who are the research sample. Analysis of research data using frequency distribution techniques with the calculation of the percentage of $\mathrm{P}=$ $\mathrm{F} / \mathrm{N} \times 100 \%$. Based on the answers of 25 students who were respondents, the mean score for the indicator of student motivation was 3.88 with a percentage level of $77.66 \%$ classified as good, the mean for the indicator of participation of the school principal 3.47 with the level the percentage of $69.42 \%$ is classified well, and the average for the indicators of facilities and infrastructure is 3.39 with a percentage level of $67.71 \%$ classified as good. Thus the results of the overall indicators above obtained an average (mean) of 3.58 with a percentage of $71.60 \%$ and it can be concluded that the implementation of badminton extracurricular activities at SMAN 12 Padang is in the good category.
\end{abstract}

\section{Keywords: Badminton Extracurricular Implementation}

\section{INTRODUCTION}

National education aims to help achieving optimal development for each individual with potential in himself, "National education functions to develop capabilities and forming the character and civilization of the nation and dignity in order to educate the nation's life aims to develop the potential of students to become human beings who believe and fear the Almighty God, are noble, healthy, knowledgeable, capable, creative, independent and become citizens of democratic countries and responsible"[1].

The purpose of this education, one of which is through physical education at school, the implementation of physical education in schools has been outlined in the curriculum in the form of intracurricular, cochurricular and extracurricular activities.

Extracurricular activities are activities carried out outside of face-to-face learning hours (including holidays) in face-to-face meetings. Extracurricular activities are activities carried out outside of face-to-face lessons.

From the process of implementing badminton extracurricular activities, it should work well because badminton is an interesting and easy game to learn, through this badminton extracurricular activity, it can also improve students' physical fitness, and can improve achievement in sports.

To improve students' skills, need to be added to the time taken outside of school hours and known as extracurricular activities. According to the author the purpose of extracurricular activities is to form, develop and enhance the creativity and achievements of students.
"Efforts to develop the potential of students so that they develop to reach the maximum stage, not only understand intracurricular activities but are also supported by extracurricular activities. It can contribute more than intracurricular activities if managed as well as possible in order to channel and cultivate one's talents"[2].

From what was stated above, it is clear that extracurricular development activities can contribute to intracurricular activities. Besides, it is a place for children (students) who have the potential to channel their talents and interests in a sport, especially children who are gifted and have good interests to be able to develop their achievements in accordance with the sports they enjoy.

Judging from the process of implementing badminton extracurricular activities at SMAN 12 Padang, it should work well because badminton is an interesting and easy game to learn, through badminton extracurricular activities, it can also improve students' physical fitness, and can improve performance in sports.

However, the implementation of badminton extracurricular activities at SMAN 12 Padang is still far from what is expected. This can be seen from the lack of badminton achievement obtained by SMAN 12 Padang students, and the lack of enthusiasm of students in participating in badminton extracurricular activities. Evidenced by the low attendance of students in participating in extracurricular activities and seen from the school field which is less motivating students to extracurricular activities so that badminton extracurricular activities are carried out in a separate place with the school. 
In badminton extracurricular activities students are not accompanied by a coach, whereas the role of the trainer is also very important in improving student achievement in badminton and the lack of role of physical education teachers in these activities as well as a lack of participation from principals as seen from the lack of school attention to the completeness of badminton facilities and infrastructure, because of the cost of each student to rent a hall / field and shuttlecock so that this activity is carried out.

This problem may be due to the school's lack of seriousness and lack of understanding and attention to extracurricular activities. Likewise, the support of parents of students who are not less important to motivate students to participate in badminton extracurricular activities. Looking at the problems found above, the researchers were interested in conducting research related to "Review of the Implementation of Badminton Extracurricular Activities at SMAN 12 Padang.

\section{RESEARCH METHODS}

Based on the problems to be investigated, this study includes descriptive research. Descriptive research is a study that describes or focuses attention on an actual problem that is occurring and obtained data from the situation without any engineering from the data[3]. which aims to describe or know how to implement badminton extracurricular activities at SMAN 12 Padang.

the whole element that will be explained by a researcher in his research[4]. The population of this study was all students of SMAN 12 Padang who actively participated in badminton extracurricular activities as many as 25 people in class $\mathrm{X}$ and class XI.

"The sample is part of the number of characteristics possessed by the population"[5]. After counting the population there were 25 people, namely, students of class X numbered 16 people, and students of class XI numbered 9 people, because the population was less than 100 . The sampling technique in this study using total sampling technique is the population sampled, because the population is less than 100 people[6].

The data collected in this study were then analyzed using descriptive technical analysis as follows: examine all questionnaires that were filled in by students of SMAN 12 Padang, make a table of preparation and tabulation of data, calculate the frequency and alternatives provided using the formula [7].

To determine the level of answers from respondents to the statements in the study carried out by comparing the scores obtained from the data with the scores that should be achieved, by grouping which is made as follows to determine the assessment category used is classification [8]:

$\begin{array}{ll}81-100 \% & : \text { Very good } \\ 61-80 \% & : \text { Good } \\ 41-60 \% & \text { : Fair } \\ 21-40 \% & \text { : Poor } \\ \text { I-20 } & \text { : Very Poor }\end{array}$

\section{RESULTS AND DISCUSSION}

Based on the research that has been done by distributing questionnaires for the implementation of extracurricular activities for badminton at 12 Padang High School, the following points were found:

\subsection{Level of Student Motivation}

Based on the overall statement on the motivation indicators of Padang State High School 12 students towards badminton extracurricular data obtained 267 student responses with a percentage of $26 \%$ who strongly agreed, 477 student responses with percentages $47 \%$ who agreed, 184 student responses with an $18 \%$ percentage who expressed doubts, 88 student responses with a percentage of $9 \%$ who expressed disagreement and 9 student responses with a percentage of $1 \%$ who stated strongly disagree. Obtained an average $=3.88$ with a percentage of $77.66 \%$. So it can be concluded, for the motivation indicators of Padang State High School 12 students towards badminton extracurricular activities are categorized as good (for more details, see the table below)

Table 1. Student Statement conclusions on indicators of Student Motivation.

\begin{tabular}{|c|c|c|}
\hline Students & Percentage & Strongly agree \\
\hline 267 & $26 \%$ & Agree \\
\hline 477 & $47 \%$ & Doubtful \\
\hline 184 & $18 \%$ & Disagree \\
\hline 88 & $9 \%$ & Strongly disagree \\
\hline 9 & $1 \%$ & Strongly agree \\
\hline
\end{tabular}

\subsection{Level of School Principal Participation}

Based on the overall statement on the indicators of participation of principals in badminton extracurricular data obtained 46 responses of students with a percentage of $14 \%$ who stated strongly agree, 131 responses of students with a percentage of $40 \%$ who agreed, 98 responses of students with a percentage of $30 \%$ who expressed doubt doubts, 30 responses of students with a percentage of $9 \%$ who expressed disagreement and 20 responses of students with a percentage of $6 \%$ who stated strongly disagree. Obtained an average $=3.47$ with a percentage of $69.42 \%$. So it can be concluded, for the indicator of the participation of school principals in badminton extracurricular activities it is categorized as good (for more details, see the table below).

Table 2. Conclusion of Students Statement on Indicators of Principal Participation.

\begin{tabular}{|c|c|c|}
\hline Student & Percentage & Statement \\
\hline 46 & $14 \%$ & Strongly agree \\
\hline 131 & $40 \%$ & Agree \\
\hline 98 & $30 \%$ & Doubtful \\
\hline 30 & $9 \%$ & Disagree \\
\hline 20 & $6 \%$ & Strongly disagree \\
\hline & Completeness of Facilities and Infrastructures
\end{tabular}

From the overall statement on indicators of extracurricular facilities and infrastructure badminton data obtained 73 responses of students with a percentage of $21 \%$ 
who stated strongly agree, 108 responses of students with a percentage of $31 \%$ who agreed, 72 responses of students with a percentage of $21 \%$ who expressed doubt, 75 responses of students with a percentage of $21 \%$ who expressed disagreement, and 22 student responses with a percentage of $6 \%$ stated strongly disagree. Obtained an average $=3.38$ with a percentage of $67.71 \%$. Then it can be concluded, for the indicators of facilities and infrastructure for badminton extracurricular activities at SMAN 12 Padang are categorized as good (for more details can be seen in the table below).

Table 3. Conclusion Statement of Students On Indicator Infrastructures.

\begin{tabular}{|c|c|c|}
\hline Students & Percentage & Statement \\
\hline 73 & $21 \%$ & Strongly agree \\
\hline 108 & $31 \%$ & agree \\
\hline 72 & $21 \%$ & Doubtful \\
\hline 75 & $21 \%$ & Disagree \\
\hline 22 & $6 \%$ & Strongly disagree \\
\hline
\end{tabular}

So that, clearer data obtained from questionnaires can be seen in the table below:

Table 4. Data on Distribution of Questionnaires.

\begin{tabular}{|c|c|c|c|c|}
\hline Indicator & $\mathrm{N}$ & Mean & $(\%)$ & Classification \\
\hline $\begin{array}{c}\text { Motivation of } \\
\text { students }\end{array}$ & 25 & 3.88 & 77,66 & Good \\
\hline $\begin{array}{c}\text { School } \\
\text { Principal } \\
\text { Participation }\end{array}$ & 25 & 3.47 & 69.42 & Good \\
\hline $\begin{array}{c}\text { Facilities and } \\
\text { Infrastructure }\end{array}$ & 25 & 3.39 & 67.71 & Good \\
\hline Average & 25 & 3.58 & 71.60 & Good \\
\hline
\end{tabular}

Based on the results of the study, from the table above obtained the implementation of badminton extracurricular activities with a mean of 3.58 with a percentage level of 71.60 classified as good.

\section{CONCLUSION}

Based on the results of research on "the implementation of badminton extracurricular activities at 12 SMAN 12 Padang," it can be concluded:

1. From the results of data analysis and description of the implementation of badminton extracurricular activities at SMAN 12 Padang on the indicators of student motivation, classified well with the acquisition of mean $=3.88$ with a percentage of $77.66 \%$.

2. From the results of data analysis and description of the implementation of badminton extracurricular activities at SMAN 12 Padang on

3. the indicator of the participation of school principals, it was classified well with the acquisition of mean $=3.47$ with a percentage of $69.42 \%$.
4. From the results of data analysis and description of the implementation of badminton extracurricular activities at SMAN 12 Padang on the indicators of facilities and infrastructure, it is classified well with the acquisition of mean $=3.38$ with a percentage of $67.71 \%$.

From the results of the overall indicator above (mean) $=$ 3.58 with a percentage of $71.60 \%$ classified as good. So it can be concluded that the implementation of badminton extracurricular activities at SMAN 12 Padang is in the good category.

\section{REFERENCES}

[1] Republic of Indonesia Law RI Number. 20. National Education System. Jakarta: Ministry of National Education. 2003, pp 23-30.

[2] Lutan. "Human and Sports". Bandung: ITB and FPOK IKIP. 1986, pp 45-54.

[3] Lutfi "Research methods". Jakarta: PT Rajawali. 1999, pp 15-21.

[4] Prasetya. "Learning Theory, Motivation and Teaching Skills". Jakarta: Ministry of Education and Culture. 1999, pp 75-80.

[5] Sugiyono. "Business Research Methods". Bandung: CV. Alva Beta. 1999, pp 17-34.

[6] Arikunto, suharsimi. "Research Procedure A Practice Approach". Jakarta: Rineka Cipta. 1996, pp 25-35

[7] Sudjiono, Anas. "Introduction to Educational Statistics”. Jakarta: CV Rajawali. 1991, hal 58.

[8] Sudjana, Nana. "Statistical Method". Bandung: Tarsito. 1989, pp 68-78. 